\title{
Cell-free transmission of a haemic neoplasm in the cockle Cerastoderma edule
}

\author{
Catherine M. Collins ${ }^{1,2, *}$, Maire F. Mulcahy ${ }^{1}$ \\ ${ }^{1}$ National University of Ireland (UCC), Department of Zoology and Animal Ecology, \\ Lee Maltings, Prospect Row, Cork, Ireland
}

${ }^{2}$ Present address: Fisheries Research Services Marine Laboratory, Victoria Road, Torry, Aberdeen AB11 9DB, Scotland, UK

\begin{abstract}
A haemic neoplasm occurs in populations of the common cockle Cerastoderma edule L. along the coast of Ireland. The morphology, epizootiology and distribution of the disease have previously been described. The aetiology of the neoplasm is unknown. In this study transmission of the neoplasm between cockles was accomplished using both whole neoplastic cells and neoplastic cellfree homogenates which were filtered through $0.45 \mu \mathrm{m}$ Millipore filters. Successful transmission of the disease has been achieved by both methods. These results indicate that the neoplasm in cockles may have a viral aetiology. Whole neoplastic cell inoculation resulted in a higher level of disease development compared to that of cell-free inoculates. The survival rates of the inoculated groups were compared and a significant decrease in survival was found in those groups which developed the disease.
\end{abstract}

KEY WORDS: Cerastoderma edule $\cdot$ Neoplasm $\cdot$ Cell-free transmission

Resale or republication not permitted without written consent of the publisher

\section{INTRODUCTION}

The occurrence of neoplasms in shellfish has been documented since the 1960s. Such diseases have been reported in over 20 species (Elston 2000). The neoplasms consist usually of a proliferation of abnormal cells, either confined to certain tissues, e.g. gonadal tissue (Yevich \& Barry 1969, Hesselman et al. 1988), epithelial (Pekkarinen 1993) or disseminated throughout the body, and occurring in high numbers in the final disease stages. Neoplasia usually results in death of the individual, though remission has been known to occur (Appeldoorn et al. 1984, Elston et al. 1988a).

In 1982 a haemic neoplasm was detected in cockles Cerastoderma edule from Cork Harbour and Bantry Bay, on the SW coast of Ireland (Twomey \& Mulcahy 1984). Increased mortality was observed in cockles with the neoplasm (Twomey \& Mulcahy 1988). The neoplasm in $C$. edule is manifested by a population of enlarged polymorphic cells, with a high mitotic index. The nuclei are pleomorphic with prominent single, or multiple, nucleoli. They have been described as hav- ing an undifferentiated/dedifferentiated appearance (Twomey 1987).

Also found among these Irish neoplastic populations of Cerastoderma edule were 2 examples of what appeared to be germinomas. The follicles were partially or fully filled with abnormal, mitotically active cells, which appeared to arise from the germinal epithelium (Twomey 1987).

Haemic neoplasms in Cerastoderma edule from Brittany (Poder \& Auffret 1986) resembled closely those of the Irish cockles. Most molluscan species, including mussels, clams and oysters, having neoplastic diseases, show similar cytological and pathological characteristics (Elston et al. 1992). Questions remain concerning the aetiology of bivalve neoplasms. There may in fact be several aetiologies (Brown 1980), and aetiologies may vary between shellfish species. Evidence for nonbiological agents is circumstantial. It was initially considered that the high prevalence of neoplasia in cockles within Cork Harbour, Ireland, might have been related to a pollutant (Twomey 1987). However Twomey (1987) did not find higher levels of heavy metals 
(nor polychlorinated biphenyls [PCBs], Twomey 1994) within the tissues of diseased cockles from this site. It was subsequently found that the distribution of neoplasia in cockles around the Irish coast was sporadic and apparently not related to obviously polluted sites (Twomey 1994).

Where a biological aetiology has been found, the causative agent has not been definitively characterised. An infectious aetiology has been suggested for bivalve neoplasia (Oprandy et al. 1981, Oprandy \& Chang 1983, Appeldoorn et al. 1984, Elston et al. 1988b, House et al. 1998). Successful transplantation of haemic neoplasia was achieved in Cerastoderma edule from Cork Harbour (Twomey \& Mulcahy 1988). This leads to the question of whether the transplanted cells proliferate within the new host, or whether they are broken down, releasing an infectious agent, which then transforms the new host's cells.

Extensive ultrastructural examination of neoplastic cockle tissues has not shown the presence of viral particles (Twomey 1987). An attempt to transfer neoplasms between diseased and non-diseased cockles using a cell-free filtrate from neoplastic cells proved unsuccessful. It was surmised that failure may have been due to the low numbers of neoplastic cells used to prepare the filtrate and the short observation period of 3 mo. Further studies were recommended (Twomey \& Mulcahy 1988).

The aim of the present work was to attempt transmission of the neoplasm between diseased and nondiseased cockles using neoplastic cell filtrates, and thus investigate a viral aetiology to the neoplasm in these populations of shellfish.

\section{MATERIALS AND METHODS}

Five transmission experiments were conducted in total and are summarised in Table 1.

Collection of cockles. Cockles from neoplasia-free populations were collected from Woodstown Strand, County Waterford, Ireland. Cockles from neoplastic populations were collected from Cuskinny (Cork Harbour) and from Bantry (West Cork), Ireland.

Maintenance of cockles. Experimental cockles were divided into groups of 20 to 25 per 551 holding tank, containing aerated recirculating seawater. The environment within each holding tank was modified as far as possible to simulate the surroundings of the cockles in their natural habitat, with the objective of minimising stress levels within the cockles. The bottom of the containers was layered with approximately $10 \mathrm{~cm}$ of sand. Sand was sterilised by autoclaving prior to addition to the containers. The cockles were kept in semi-darkness by means of a tank cover with a slit, and the salinity of the seawater was diluted from 35\% to $26 \%$, which represented the salinity of the water from which the recipient cockles were originally taken. UVtreated seawater was used and it was changed every 2 wk. Temperature was not controlled but was allowed to fluctuate with ambient temperatures.

The cockles were fed on the flagellate alga Tetraselmis suiccici. The algae were grown in seawater which had been UV-treated and autoclaved to remove potential pathogens, thus eliminating contamination of the cockles by possible disease-causing viruses from this external source.

Detection of neoplasia in cockles. Absence of neoplastic disease in the recipient cockle population was confirmed by examination of haemolymph smears and histological sections, as described by Twomey \& Mulcahy (1988), from 30 individuals. Neoplastic cells used to prepare whole-cell and cell-free filtrate inoculates were obtained as follows. Haemolymph from cockles from neoplasia-endemic sites was examined for presence of neoplastic cells. Haemolymph was withdrawn, using a sterile syringe with a 25 gauge tuberculin needle, from the adductor muscle of cockles. Its gross morphological appearance was observed. Haemolymph of cockles with moderate to advanced levels of neoplasia appears cloudy (almost white in very severe cases), due to the density of the neoplastic cells. Less advanced cases were diagnosed by looking at haemolymph samples under phase contrast microscopy.
Table 1. Cerastoderma edule. Summary of transmission experiments. $(\mathrm{a} \times \mathrm{b})=$ no. of groups $\times$ no. of individuals per group; CFF: cell-free filtrate (cell homogenate filtered through a $0.45 \mu \mathrm{m}$ filter); normal CFF: cell-free filtrate prepared from normal (non-neoplastic) cockle haemolymph cells; treated seawater: depurated, autoclaved, Millipore filtered seawater

\begin{tabular}{|lll|}
\hline $\begin{array}{l}\text { Transmission } \\
\text { Experiment }\end{array}$ & \multicolumn{1}{c|}{ Inoculated } & \multicolumn{1}{c|}{ Control } \\
\hline I & Whole neoplastic cells $(2 \times 20)$ & Treated seawater $(2 \times 20)$ \\
& Neoplastic CFF $(2 \times 20)$ & \\
II & Whole neoplastic cells $(2 \times 25)$ & Treated seawater $(2 \times 25)$ \\
& Neoplastic CFF $(2 \times 25)$ & \\
III & Neoplastic CFF $(2 \times 27)$ & Treated seawater $(2 \times 27)$ \\
IV & Neoplastic CFF $(7 \times 35)$ & Treated seawater $(2 \times 30)$ \\
& & Normal CFF $(2 \times 30)$ \\
V & Neoplastic CFF $(5 \times 24)$ & Treated seawater $(1 \times 25)$ \\
& & Normal CFF $(2 \times 32)$ \\
\hline
\end{tabular}


Preparation of whole neoplastic cells for inoculation. Cockles were gently prised open using a mounted needle, until there was sufficient space to insert a needle into the adductor muscle. Neoplastic cells used to prepare whole cell inoculates were withdrawn from the adductor muscle of neoplastic cockles, pooled, counted using a Neubauer counting chamber, and diluted to $3 \times 10^{6}$ cells $\mathrm{ml}^{-1}$ with autoclaved Millipore filtered seawater. One hundred $\mu$ l of the cell suspension (ca. 300000 cells) was injected into the adductor muscle of individual neoplasia-free cockles.

Preparation of neoplastic cell-free filtrate. Neoplastic haemolymph was withdrawn from the adductor muscle of diseased cockles, as previously described, pooled, and diluted with autoclaved Millipore filtered seawater to a

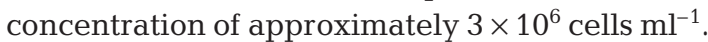

Cells were homogenised on ice using a dounce homogeniser until $>90 \%$ of the cells had been disrupted, as determined under light microscopy. The homogenate was then centrifuged at $5000 \mathrm{rpm}$ $(2200 \times g)$ for $10 \mathrm{~min}$ to remove any remaining intact cells and cell debris. The supernatant was passed through a sterile $0.45 \mu \mathrm{m}$ Millipore Millex-HV filter unit to prevent intact cells, protozoans and most bacteria from passing through, but allow passage of viruses if present.

The neoplastic haemolymph used in the following transmission studies was generally, but not exclusively, taken from cockles with moderate to advanced disease levels.

Controls. Control groups consisted of cockles injected either with autoclaved Millipore filtered seawater, or with cell free homogenate, prepared as previously, from non-neoplastic cockle haemocytes

Histology: The different inoculated groups were monitored daily, and moribund cockles were collected, bisected, and fixed in Davidson's Fixative. The tissues were processed in wax, sections of $4 \mu \mathrm{m}$ were cut and stained in Harris' haematoxylin and eosin. Haemolymph samples were not taken to observe progression of the disease; this was to minimise stress, so that the cockles might survive for as long as possible in order to allow disease development.

Fixed tissues from moribund cockles and from all cockles remaining at the conclusion of the experiment were examined for presence of neoplastic cells by light microscopy.

Staging of the disease: Staging of the disease was based on a slightly modified protocol from Mix (1983), using histological cross-sections of cockles. The disease was staged from 0 to 4 , higher numbers indicating more advanced disease stages (Table 2).
Table 2. Cerastoderma edule. Staging of the neoplasm

Description

Absence of neoplastic cells from the tissue section

Appearance of low numbers of neoplastic cells in connective tissue underlying the digestive diverticula and gonads (when present)

Migration of neoplastic cells to connective tissues away from digestive and gonadal tissues

Presence of neoplastic cells in all tissue types of individual and within haemolymph sinuses

Large concentrations of neoplastic cells throughout the body

Statistical analysis: Survival times for treatment groups were analysed using the BMDP statistical package (Statistical Solutions, SPSS), Programme 1L, and were compared between groups using the MantelCox test, a non-parametric linear rank test. The Mantel-Cox test gives equal weight to all observations.

\section{RESULTS}

\section{Transmission results}

Controls, consisting of non-neoplastic cockles inoculated with either autoclaved Millipore-filtered seawater or with a suspension of cell-free homogenate, prepared from normal cockle haemocytes, did not develop neoplasia in any of the 5 transmission experiments (Table 3).

Neoplasia was successfully transferred using both neoplastic whole-cell transplants and cell-free filtrate in both Transmission Experiments I and II. In Experiment I, $47.5 \%$ of whole cell inoculated individuals developed the disease, as did $2.5 \%$ of cell-free filtrate inoculated cockles over a period of 4 mo. Temperature ranged from 16.2 to $20.3^{\circ} \mathrm{C}$, averaging $18.1^{\circ} \mathrm{C}$ (May to September). In Transmission Experiment II, $28 \%$ of cockles receiving whole-cell transplant inoculates and $22 \%$ of cell-free filtrate recipients developed the disease over a period of $5 \mathrm{mo}$. Temperature ranged from 8.7 to $16.5^{\circ} \mathrm{C}$, averaging $11.9^{\circ} \mathrm{C}$ (December to May). Transmission of the disease was not successful in the remaining experiments, which were conducted over periods ranging from 2 to 7 mo (Table 3 ).

The staging of the neoplasm in inoculated cockles which developed the disease is summarised in Table 4. Individuals inoculated with whole neoplastic cells had a higher number of more advanced disease stages (Stage 3) compared to cell-free inoculated individuals. The number of neoplastic cells seen in tissue sections of all individuals graded as Stages 1 and 2 was very low. Only individuals graded as Stage 3 displayed high numbers of neoplastic cells. 
Table 3. Cerastoderma edule. Prevalence of neoplasia in initially disease-free cockles, inoculated with different preparations: WCT (whole neoplastic-cell transplants), CFF (neoplastic cell-free filtrates), CF-control (cell-free homogenate of normal cells) and control (Millipore filtered autoclaved seawater)

\begin{tabular}{|c|c|c|c|c|c|c|c|}
\hline \multirow{2}{*}{$\begin{array}{l}\text { Transmission } \\
\text { Experiment }\end{array}$} & \multirow{2}{*}{$\begin{array}{l}\text { Experimental } \\
\text { group }\end{array}$} & \multirow{2}{*}{$\begin{array}{c}\text { No. with } \\
\text { disease (\%) }\end{array}$} & \multirow{2}{*}{$\begin{array}{l}\text { Experiment } \\
\text { duration (d) }\end{array}$} & \multirow[t]{2}{*}{ Season } & \multicolumn{3}{|c|}{ —Temperature $\left({ }^{\circ} \mathrm{C}\right)$} \\
\hline & & & & & Ave. & Max. & Min \\
\hline \multirow[b]{3}{*}{ I } & WCT & $19 / 40(47.5)$ & \multirow{3}{*}{125} & \multirow{3}{*}{ May-Sep } & \multirow{3}{*}{18.1} & \multirow{3}{*}{20.3} & \multirow{3}{*}{16.2} \\
\hline & CFF & $1 / 40(2.5)$ & & & & & \\
\hline & Control & $0 / 40(0)$ & & & & & \\
\hline \multirow[b]{3}{*}{ II } & WCT & $14 / 50(28)$ & \multirow{3}{*}{169} & \multirow{3}{*}{ Dec-May } & \multirow{3}{*}{11.9} & \multirow{3}{*}{16.5} & \multirow{3}{*}{8.7} \\
\hline & $\mathrm{CFF}$ & $11 / 50(22)$ & & & & & \\
\hline & Control & $0 / 50(0)$ & & & & & \\
\hline \multirow[b]{2}{*}{ III } & $\mathrm{CFF}$ & $0 / 54(0)$ & \multirow[t]{2}{*}{57} & \multirow[t]{2}{*}{ Jan-Mar } & \multirow[t]{2}{*}{10.8} & \multirow[t]{2}{*}{14.5} & \multirow[t]{2}{*}{7.0} \\
\hline & Control & $0 / 54(0)$ & & & & & \\
\hline \multirow[b]{3}{*}{ IV } & CF-control & $0 / 60(0)$ & \multirow{3}{*}{106} & \multirow{3}{*}{ Apr-Aug } & \multirow{3}{*}{22.1} & \multirow{3}{*}{25.5} & \multirow{3}{*}{12.5} \\
\hline & $\mathrm{CFF}$ & $0 / 245(0)$ & & & & & \\
\hline & Control & $0 / 60(0)$ & & & & & \\
\hline \multirow[b]{3}{*}{$\mathrm{V}$} & CF-control & $0 / 64(0)$ & \multirow{3}{*}{223} & \multirow{3}{*}{ Nov-Jun } & \multirow{3}{*}{13.4} & \multirow{3}{*}{20.7} & \multirow{3}{*}{6.0} \\
\hline & $\mathrm{CFF}$ & $0 / 120(0)$ & & & & & \\
\hline & Control & $0 / 25(0)$ & & & & & \\
\hline
\end{tabular}

Table 4. Cerastoderma edule. Distribution of disease stages within cockles which developed the disease when inoculated with different preparations: WCT (whole neoplastic-cell transplants), CFF (neoplastic cell-free filtrates)

\begin{tabular}{|c|c|c|c|c|c|c|}
\hline \multirow{2}{*}{$\begin{array}{c}\text { Transmission } \\
\text { Experiment }\end{array}$} & \multirow{2}{*}{ Inoculate } & & & \multirow{2}{*}{$\begin{array}{c}\text { Disease stage } \\
\text { Stage } 2\end{array}$} & \multirow[b]{2}{*}{ Stage 3} & \multirow[b]{2}{*}{ Stage 4} \\
\hline & & Stage 0 & Stage 1 & & & \\
\hline \multirow[t]{2}{*}{ I } & WCT & 21 & 3 & 14 & 2 & 0 \\
\hline & CFF & 39 & 0 & 1 & 0 & 0 \\
\hline \multirow[t]{2}{*}{ II } & WCT & 36 & 2 & 9 & 3 & 0 \\
\hline & $\mathrm{CFF}$ & 39 & 1 & 10 & 0 & 0 \\
\hline
\end{tabular}

\section{Survival analysis}

Transmission Experiment I

The survival of cockles in the 3 experimental groups involved was examined.

A 3-way analysis was firstly carried out on the experimental groups. The statistical analysis indicated that there was evidence of differences in survival times between the 3 groups (Mantel-Cox $=52.9$; $\mathrm{p}<0.0001$ ). A pair-wise comparison was therefore carried out.

There was very strong evidence that the survival rate of whole neoplastic-cell transplants (WCT) differed from that of the neoplastic cell-free filtrates (CFF) control groups (Mantel-Cox $=40.5$, p $<0.0001$, and Mantel-Cox $=32.9, \mathrm{p}<0.0001$, respectively). The difference in survival rate was greatest towards the end of the experiment.

Results also indicate that there was no significant difference in survival rate for the CFF and control groups (Mantel-Cox $=1.0$, non-significant [NS]), though as indicated by Fig. 1a, survival rate was lower in the CFF group than in the control group at the beginning of the experiment.

Results of survival comparisons are summarised in Table 5 .

\section{Transmission Experiment II}

The survival of cockles in the 3 experimental groups was examined as described for Transmission Experiment I.

Three-way comparison of survival times between the experimental groups indicate that there is a difference in survival rate between the groups (MantelCox $=12.5, \mathrm{p}<0.01$ ).

Pair-wise analysis indicates that there is little difference between survival rate for the WCT and CFF groups (Mantel-Cox $=1.1$, NS). This can also be seen from Fig. $1 \mathrm{~b}$.

Results of the Mantel-Cox analysis indicate that there is a difference in survival rate between the WCT and 


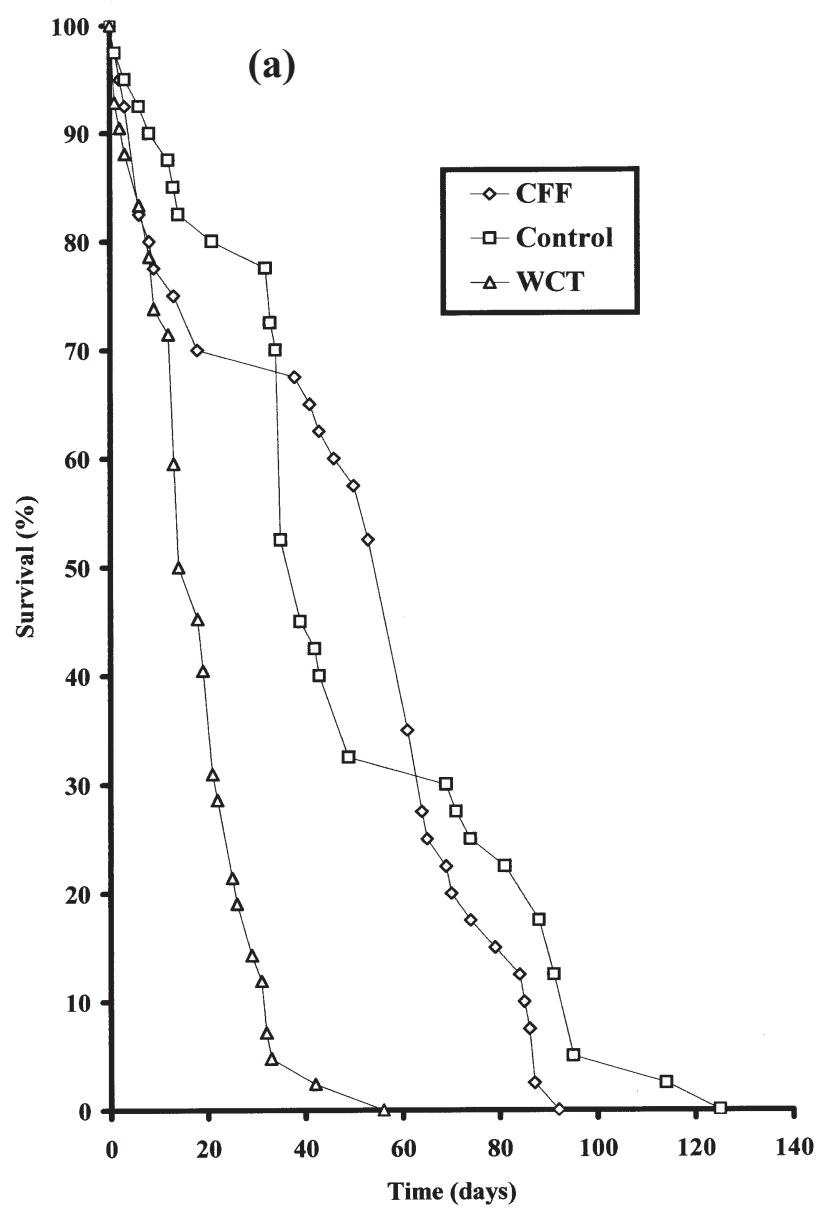

(b)

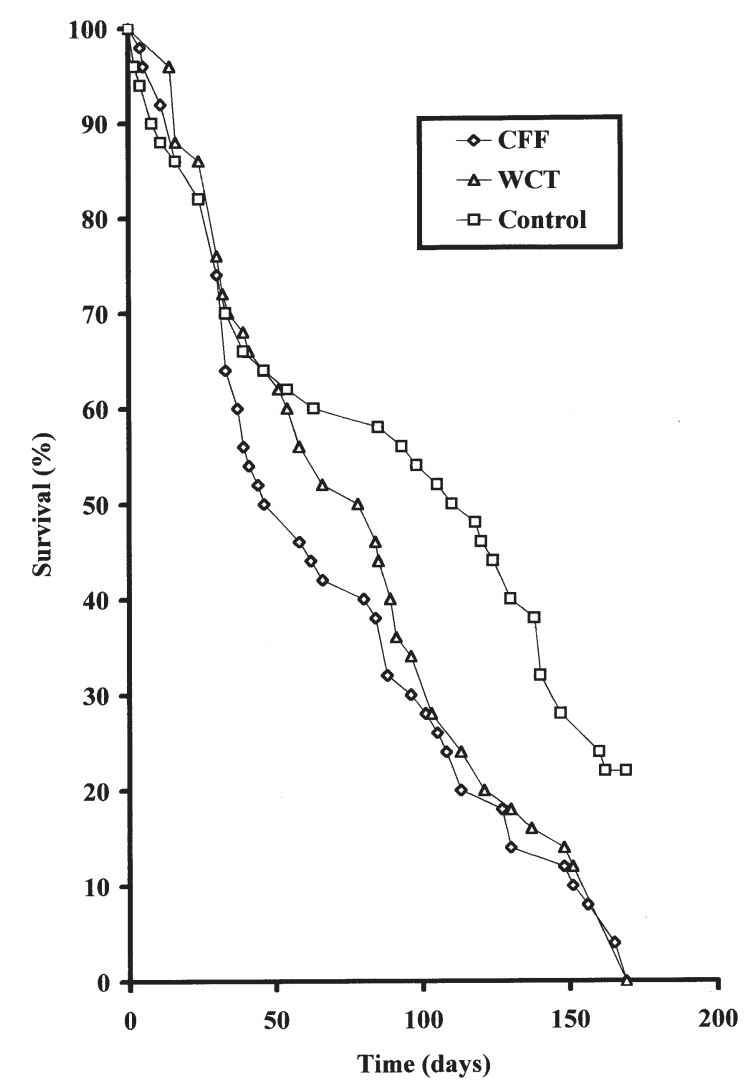

Fig. 1. Cerastoderma edule. Percentage survival over time (days) of inoculated groups in Transmission Experiments I (a) and II (b). WCT: whole neoplastic-cell inoculated individuals; CFF: neoplastic cell-free filtrate inoculated individuals; control: Millipore filtered, autoclaved seawater

control groups (Mantel-Cox $=6.6, \mathrm{p}<0.01$ ) and between the CFF and control groups (Mantel-Cox $=10.2$, $\mathrm{p}<0.01$ ), the control group displaying a greater survival rate in both cases. The pattern of differences in survival rate for both pairings can be seen from Fig. 1b. Results of survival comparisons are summarised in Table 5.

None of the remaining experiments differed in survival rates between groups (3-way comparisons of survival times between the groups gave values of: Transmission Experiment III, Mantel-Cox $=2.3$, NS; Transmission Experiment IV, Mantel-Cox $=3.6, \mathrm{NS}$; Transmission Experiment V, Mantel-Cox $=0.0$, NS.

\section{DISCUSSION}

In 2 of the 5 experiments, cockles inoculated with neoplastic filtrate developed neoplasia. In both of these experiments, both whole cell-injected and cell-free filtrate-injected cockles developed the disease. Control animals did not develop the neoplasm. It would appear from the results of Transmission Experiments I and II, that the neoplasm in the cockle Cerastoderma edule is caused by a virus (or at least by an as yet unidentified infectious particle), since the filtrate obtained from the homogenised neoplastic cells was passed through a $0.45 \mu \mathrm{m}$ filter subsequent to centrifugation, and most bacteria, protozoan organisms and whole neoplastic cells would have been excluded by this method.

The results obtained here, which support a viral aetiology for haemic neoplasm in cockles, agree with those found for aetiology of neoplasms in other bivalve species. Oprandy et al. (1981) and Appeldoorn et al. (1984) isolated a viral fraction from Mya arenaria with haemic neoplasia, which was subsequently used to fulfill Koch's postulates. Attempts to transmit the neoplasm to non-neoplastic $M$. arenaria using cell-free filtrates from neoplastic Mуа sp. failed (McLaughlin et al. 1992), but in this study the filtrate was passed through a $0.22 \mu \mathrm{m}$ filter before inoculation, and filters of this pore size are known to retain many viral particles. Therefore this negative result does not necessarily 
exclude the possibility of a viral aetiology. Reverse transcriptase activity, indicative of the presence of retroviruses and often involved in mammalian cancers, had been detected in extracts from neoplastic individuals of $M$. arenaria, but not from healthy individuals (House et al. 1998). In the study carried out by Elston et al. (1988b), mussels Mytilus edulis which were injected with neoplastic cell homogenate developed haemic neoplasms; controls, however, also developed the disease, leaving the results ambiguous.

Three of the 5 transmission experiments, using neoplastic cell-free homogenate, did not result in disease development. The inconsistency in the success of the 5 transmission studies carried out here is not very surprising, assuming a viral cause of the disease. Viruses which cause transformation are not always, in fact rarely, expressed as viral particles in the transformed cell: they remain integrated into the host-cell genome, from where they exert their influence. It may therefore be only on certain rare occasions, in the presence of auxiliary factors, that viral particles can actually be isolated from the cells.

Failure of transmission experiments may also be due not to absence of a virus, but to use of a cell from which to prepare cell-free homogenate, different to that in which the virus is transmitted in an infectious state. A viral fraction (consisting of $100 \mathrm{~nm}$ icosahedral particles) was identified in a homogenate of ova isolated from neoplastic Mya arenaria (Sunila 1994). When isolated ova from neoplastic clams were injected into healthy recipients, these clams developed a haemic neoplasm. This led Sunila to propose that the transportation of the infection in the field is most likely carried out by ova.

Successful transmission of neoplasia by transplants of whole cells was achieved in Experiments I and II, as was reported previously by Twomey \& Mulcahy (1988). Cockles which developed neoplasia as a result of whole neoplastic cell inoculates displayed more advanced stages of the disease overall compared to cockles developing neoplasia after inoculation of neoplastic cell-free filtrate. This was also seen in parallel

Table 5. Cerastoderma edule. Survival of experimental groups within each experiment, compared using the Mantel-Cox test. NS: non-significant

\begin{tabular}{|llcc|}
\hline $\begin{array}{l}\text { Transmission } \\
\text { Experiment }\end{array}$ & Experimental group & $\begin{array}{c}\text { Mantel-Cox } \\
\text { statistic }\end{array}$ & $\mathrm{p}<$ \\
\hline I & Whole cell vs control & 40.5 & 0.0001 \\
& Cell filtrate vs control & 1.0 & $\mathrm{NS}$ \\
& Whole cell vs cell filtrate & 32.9 & 0.0001 \\
& & & 0.01 \\
II & Whole cell vs control & 6.6 & 0.01 \\
& Cell filtrate vs control & 10.2 & $\mathrm{NS}$ \\
\hline
\end{tabular}

inoculations of mussels with neoplastic cell-free filtrate and whole cells. In mussels which developed the disease, while both inoculated groups ultimately developed similar disease prevalences, disease developed more slowly in the cell-free-filtrate-inoculated individuals (Elston et al. 1988b). The environment within an inoculated neoplastic cell, subjected to degradation in the new host, may trigger excision of a viral particle in an actively transforming state. This might increase the rate of infection of new cells compared to viral particles excised from neoplastic cells during preparation of a cell-free filtrate. The faster initial rate of development of neoplasia in whole-cell-inoculated individuals may also be due to direct replication and proliferation of the inoculated whole neoplastic cells. This would eliminate the time needed for free viral particles in cell-free filtrates to infect (a relatively rare event), adjust to the cell environment, and cause transformation of a cell.

Differences in survival rate were seen between the experimental groups in Transmission Experiment I. Significantly decreased survival was seen in the whole-cell-inoculated group, of which $47 \%$ developed neoplasia, compared either to groups inoculated with neoplastic cell homogenate, $2.5 \%$ of which developed the disease, or to control groups. Differences in survival rates were also seen between the experimental groups in Transmission Experiment II. In this experiment, both whole-cell transplants and cell-free-filtrateinoculated groups showed significantly decreased survival rates compared with the control group. It would appear that establishment of the disease within the whole-cell inoculated group in Transmission Experiment I, and both whole-cell-inoculated and cell-homogenate-inoculated groups in Transmission Experiment II, decreased the survival rate of the cockles. The remaining transmission experiments (Transmission Experiments III to V), did not differ significantly in survival rates between the experimental groups. It must be noted that when compared to controls, even though survival rate was significantly lower in those groups in which neoplasms developed, the level of survival within control animals was in itself abnormally low. Reasons for this are unknown. Thus, while development of the neoplasm can be said to affect the survival rate of the cockles under the experimental conditions, possible effects on cockle survival under natural conditions cannot be commented upon. Decreased survival in diseased cockles may be due to the replacement of normal tissues by neoplastic cells, or to substances produced by neoplastic cell metabolism which are specifically or non-specifically toxic to normal cells. 
Sunila (1992) inoculated clams with normal cells suspended in neoplastic serum. These clams did not develop the disease but they did display increased mortality rates. Presence of cytotoxic factors in the neoplastic serum was suggested as a possible cause for this, similar to cytotoxic factors aiding metastasis in mammalian cancers (Diamandopoulos \& Meissner 1985). Brown et al. (1977) observed necrosis of tissues surrounding neoplastic cell foci in Mya arenaria, indicating the possible excretion of cytotoxic factors by these abnormal cells. These substances may also be bacterial toxins secreted into the serum of neoplastic individuals (Sunila 1992). Bivalve neoplastic cells are generally thought to be less able to combat bacterial infections due to an inability to adhere and phagocytose foreign particles (Beckmann et al. 1992). This results in high bacterial loads and therefore possible high bacterial toxin levels (Kent et al. 1989).

A viral aetiology to the cockle neoplasm is supported by the successful transmission of the disease using cell-free homogenates from neoplastic cells. Ultimately, the most definitive proof of a viral aetiology for haemic neoplasia in Cerastoderma edule involves the isolation of viral particles from neoplastic tissues, transmission of the disease using these fractions and their re-isolation. This has been achieved in the case of haemic neoplasia of Mya arenaria (Oprandy et al. 1981, Appeldoorn et al. 1984). Because oncogenic viruses are rarely expressed as free particles within transformed cells, methods for inducing their proliferation in mammalian systems should be adapted to bivalve systems in an attempt to successfully isolate viruses implicated in bivalve neoplasms.

Acknowledgements. The authors would like to thank Dr. Éamonn Ó Tuama, Marine Coastal Resources Centre, University College Cork, Ireland, for his help and advice.

\section{LITERATURE CITED}

Appeldoorn RS, Brown CW, Brown RS, Chang PW and 5 others (1984) Field and laboratory studies to define the occurrence of neoplasia in the soft-shell clam, Mya arenaria. American Petroleum Institute Publication 4345. American Petroleum Institute, Washington, DC

Beckmann N, Morse PM, Moore CM (1992) Comparative study of phagocytosis in normal and diseased hemocytes of the Bivalve Mollusc, Mya arenaria. J Invertebr Pathol 59:124-132

Brown RS (1980) The value of the multidisciplinary approach to research on marine pollution effects as evidenced in a 3 year study to determine the etiology and the pathogenesis of neoplasia in the soft-shell clam, Mya arenaria. Rapp P-V Rèun Cons Int Explor Mer 48:208-215

Brown RS, Wolke RE, Saila SB, Brown CW (1977) Prevalence of neoplasia in $10 \mathrm{New}$ England populations of the soft shell clam. Ann N Y Acad Sci 298:522-534

Diamandopoulos G, Meissner W (1985) Neoplasia. In: Kissane JM (ed) Anderson's pathology. CV Mosby, St Louis, MO, p 514-559

Editorial responsibility: Albert Sparks,

Seattle, Washington, USA
Elston RA (2000) Molluscan diseases: a tissue culture perspective. In: Mothersill C, Austin B (eds) Aquatic invertebrate cell culture. Springer-Verlag, New York, p 183-204

Elston RA, Kent ML, Drum AS (1988a) Progression, lethality and remission of hemic neoplasia in the bay mussel Mytilus edulis. Dis Aquat Org 4:135-142

Elston RA, Kent ML, Drum AS (1988b) Transmission of hemic neoplasia in the bay mussel, Mytilus edulis, using whole cells and cell homogenate. Dev Comp Immunol 12:719-727

Elston RA, Moore JD, Brooks K (1992) Disseminated neoplasia of bivalve molluscs. Rev Aquat Sci 6(5/6):405-466

Hesselman DM, Blake NJ, Peters EC (1988) Gonadal neoplasms in hard shell clams Mercenaria spp., from the Indian River, Florida: occurrence, prevalence and histopathology. J Invertebr Pathol 52:436-446

House ML, Kim CH, Reno PW (1998) Soft shell clams Mya arenaria with disseminated neoplasia demonstrate reverse transcriptase activity. Dis Aquat Org 34:187-192

Kent ML, Elston RA, Wilkinson MT, Drum AS (1989) Impaired defence mechanisms in Bay Mussels, Mytilus edulis, with hemic neoplasia. J Invertebr Pathol 53:378-386

McLaughlin SM, Farley AC, Hetrick FM (1992) Transmission studies of sarcoma in the soft shell clam, Mya arenaria. In Vivo 6:367-370

Mix MC (1983) Haemic neoplasms of Bay Mussels, Mytilus edulis L., from Oregon: occurrence, prevalence, seasonality and histopathological progression. J Fish Dis 6:239-248

Oprandy JJ, Chang PW (1983) 5-Bromodeoxyuridine induction of haemopoeitic neoplasia and retrovirus activation in the soft-shell clam, Mya arenaria. J Invertebr Pathol 40: 196-206

Oprandy JJ, Chang PW, Pronovost AD, Cooper KR, Brown RS, Yates VJ (1981) Isolation of a viral agent causing hematopoietic neoplasia in the soft-shell clam, Mya arenaria. J Invertebr Pathol 38:45-51

Pekkarinen M (1993) Neoplastic diseases in the Baltic Macoma balthica (Bivalvia) off the Finnish coast. J Invertebr Pathol 61:138-146

Poder M, Auffret M (1986) Sarcomatous lesion in the cockle Cerastoderma edule L.: morphology and population survey in Brittany, France. Aquaculture 58:1-8

Sunila I (1992) Serum-cell interactions in transmission of sarcoma in the soft shell clam, Mya arenaria L. Comp Biochem Physiol 102A(4):727-730

Sunila I (1994) Viral transmission and tumour promotion of sarcoma in the soft shell clam, Mya arenaria L. In: Rosenfield A, Kern FG, Keller BJ (eds) Invertebrate Neoplasia: initiation and promotion mechanisms. NOAA Technical Memorandum, NMFS-NE-107. Proc Int Workshop, 23 June 1992, Washington, DC. US Dept. of Commerce, National Oceanic and Atmospheric Administration, National Marine Fisheries Service, Northeast Region, Northeast Fisheries Science Center, Woods Hole, MA, p 11-13

Twomey E (1987) A sarcoma of the cockle Cerastoderma edule. PhD thesis, National University of Ireland, Cork

Twomey E (1994) Distribution of a sarcoma in the cockle, Cerastoderma edule around the Irish coast 1982-1991: implications for a pollutant aetiology. NOAA Technical Memorandum, NMFS-NE-107

Twomey E, Mulcahy MF (1984) A proliferative disorder of possible haemic origin in the common cockle, Cerastoderma edule. J Invertebr Pathol 44:109-111

Twomey E, Mulcahy MF (1988) Transmission of a sarcoma in the cockle Cerastoderma edule (Bivalvia; Mollusca) using cell transplants. Dev Comp Immunol 12:195-200

Yevich PP, Barry MM (1969) Ovarian tumours in the Quahog Mercenaria mercenaria. J Invertebr Pathol 14:266-267

Submitted: May 31, 2000; Accepted: August 25, 2002

Proofs received from author(s): February 16, 2003 